\title{
REPRESENTASI KESETARAAN GENDER DALAM UNDANG-UNDANG PEMILU SERTA PENERAPANNYA BAGI PEREMPUAN BALI
}

\author{
Oleh: \\ I Made Adi Widnyana ${ }^{1}$ \\ E-mail: adiwidnyana@ihdn.ac.id \\ Dosen Jurusan Hukum Fakultas Dharma Duta IHDN Denpasar
}

\begin{abstract}
The purpose of this paper is to see the extent to which the Election Law is able to address gender equality in politics and democracy and how Balinese women apply this provision as an opportunity to advance and align themselves in the political field by looking at the results of the elections in Bali. So based on that research method used is normative research that refers to the provisions of applicable regulations and is supported by sources of literature and supporting data.

It is known that the Election Law requires a $30 \%$ quota requirement for women's representation in the electoral process of each political party. This will be an opportunity for women to be able to align themselves and dilute the backwardness of men who used to dominate, although it is known that this cannot be said to be equal or balanced, but at least women are guaranteed their opportunity to be certain in politics through opportunities chosen rights they have.

Balinese women from the results of the implementation of the 2004 legislative elections to 2019 for women's representation in the Bali Provincial DPRD, were able to show a significant increase in representation, so it can be said that Balinese women from time to time are able to take advantage of opportunities and opportunities to participate in the political and democratic equalization.
\end{abstract}

Keyword: Equality, Gender, Women, Elections

\section{PENDAHULUAN}

Berbicara tentang kesetaraan gender tentu tidak dapat dilepaskan dari kesetaraan dari hak-hak dan tanggung jawab kaum perempuan yang dalam perkembangannya mulai disejajarkan dengan hak-hak kaum pria diberbagai bidang kehidupan. Hak-hak dan tanggung jawab ini tidak hanya sebatas ada pada pekerjaan rumah tangga semata, namun sudah mencakup tentang hak - hak yang menyentuh ranah profesi bahkan spesialisasi. Kaum perempuan saat ini tidaklah dapat dipandang sebelah mata, karena mereka juga memiliki kemampuan dan keahlian untuk dapat memperoleh dan memperjuangkan hak-hak dan tanggung jawab mereka, oleh karenanya hak dan tanggung jawab tersebut tidaklah mereka dapatkan secara kodrati namun berkat perjuangan serta pemenuhan diri akan unsur-unsur kelayakan dan kepatutan untuk mendapatkan hak dan tanggung jawab tersebut.

Kebangkitan kaum wanita di Indonesia telah dimulai dari masa perjuangan sebelum kemerdekaan dengan Raden Ajeng Kartini mempelopori kebangkita kaum wanita di bidang pendidikan (Mardanas Safwan, 2001). Kebangkitan kaum peremuan di bidang pendidikan menghantarkan mereka memiliki posisi yang sejajar dengan kaum pria yang dianggap pada masa dahulu lebih layak untuk 
bersekolah. Hal ini menyebabkan di masa sekarang banyak kaum perempuan yang memegang peran strategis dan fundamental dalam bingkai kenegaraan Indonesia. Sebut saja $\mathrm{Hj}$. Megawati Soekarnoputri, perempuan pertama di Indonesia yang sempat menduduki posisi sebagai Presiden Republik Indonesia Tahun 2001-2004, sebuah posisi kehormatan tertinggi dalam kelembagaan eksekutif Negara. Berikutnya ada deretan kaum perempuan yang menduduki jabatan menteri mulai dari era pemerintahan Soekarno hingga pemerintahan Joko Widodo saat ini ada 32 perempuan hebat yang pernah menduduki jabatan sebagai Menteri (Wikipedia, akses: 1 Juli 2019). Diantaranya yang dapat dilihat saat ini sedang menjadi kebanggaan duduk di kabinet kerja Pemerintahan bapak Joko Widodo seperti: Susi Pudjiastuti, Puan Maharani, Retno Marsudi, Nila Moeloek, Siti Nurbaya Bakar, Yohana Yembise, dan Sri Mulyani. Tidak hanya itu kaum perempuan juga merambah posisi di kepala daerah, kelembagaan non struktural, akademi, profesi, dan lainnya.

Namun disadari bahwa, kaum perempuan tidak dapat lepas dari bayang-bayang kodrati mereka sebagai perempuan yang mewajibkan mereka untuk mengurusi urusan rumah tangga dan keluarga, karena dalam berbagai hukum adat dan hukum agama yang berlaku di Indonesia, umumnya menempatkan perempuan atau wanita sebagai subjek pendamping kaum pria, yang mengakibatkan mereka tidak dapat tampil terdepan dalam suatu permasalahan atau tanggungjawab. Hal ini juga yang kadangkala berimbas pada penilaian sebagian masyarakat akan keberadaan kaum perempuan yang dianggap tidak layak untuk diangkat atau dipilih sebagai pemimpin walaupun memiliki kemampuan, sehingga jika hal ini dibiarkan maka perjuangan kaum perempuan yang telah ada sampai saat ini tidak akan mampu berkembang secara maksimal dalam mencapai kesetaraan tersebut. Untuk dapat tetap mempertahankan eksestensi kaum perempuan dalam berbagai bidang kehidupan dibutuhkan suatu kebijakan serta aturan yang dapat memayungi dan menjamin keberlangsungan kaum perempuan untuk dapat berpartisipasi dan terlibat di dalamnya. Jika kita melihat perjuangan pendiri Negara Indonesia, sebenarnya eksistensi kaum perempuan tidak perlu dirisaukan karena di dalam konstitusi dasar kita tepatnya Pasal 27 ayat (1) Undang-Undang Dasar 1945, telah menjelaskan adanya pengakuan terhadap prinsip persamaan bagi seluruh warga negara tanpa kecuali. Prinsip persamaan ini menghapuskan diskriminasi, karenanya setiap warga negara mempunyai hak yang sama di hadapan hukum dan pemerintahan tanpa memandang agama, suku, jenis kelamin, kedudukan, dan golongan. Moempoeni Martojo mengatakan bahwa: "Istilah warga negara sudah barang tentu mengandung pengertian baik wanita maupun pria". Apa yang dikemukakan oleh Moempoeni Martojo adalah benar, sebab di mana pun negara di dunia ini, warga negaranya selalu terdiri dari laki-laki dan perempuan. Dengan adanya pengakuan persamaan hak warga negara, berarti antara laki-laki dengan perempuan tidak ada perbedaan. Diakuinya prinsip persamaan di hadapan hukum dan pemerintahan di dalam UUD menunjukkan para pendiri negara Indonesia, sebelum mendirikan negara, sadar betul tentang arti pentingnya perlindungan terhadap hak asasi manusia itu (Moempoeni Martojo, 1999). 
Walaupun pengaturan pelarangan diskriminasi ini masih terlihat implisit namun wujud kongkrit dari pengaturan tentang hak-hak persamaan ini terlihat setelah diberlakukannya UndangUndang Nomor 39 Tahun 1999 tentang Hak Asasi Manusia, yang didalam dalam Pasal 3 ayat (3), yang berbunyi: "Setiap orang berhak atas perlindungan hak asasi manusia dan kebebasan dasar manusia, tanpa diskriminasi". Pasal 1 ayat (3) dan Pasal 3 ayat (3) UU No. 39 Tahun 1999 ini menjelaskan bahwa diskriminasi berdasarkan jenis kelamin telah dilarang oleh hukum. Aturan hukum lainnya harus meniadakan diskriminasi dalam setiap aspek kehidupan, sosial, politik, ekonomi, budaya dan hukum.

Dalam tulisan ini, dengan menggunakan metode penelitian secara normatif dengan pendekatan peraturan hukum serta studi kepustakaan dan data-data penunjang lainnya, kita akan melihat sejauhmana ketentuan Undangundang yang mengatur kesetaraan di dalam aspek politik bagi perempuan. Sehingga dapat diambil contoh perjuangan memperoleh hak di bidang politik tersebut, dengan melihat sejauhmana pencapaian perempuan Bali dalam menduduki kursi DPRD Tk 1, sebagai bagian dari representasi pencapaian politik perempuan di Bali.

\section{PEMBAHASAN}

\section{A. Representasi Kesetaraan Perempuan Dalam Undang - Undang Pemilu}

Walaupun diketahui bahwa kesetaraan perempuan di dalam politik dan demokrasi saat ini masih dibelakang kaum pria, yang dilihat dari jumlah keikutsertaan dalam kontestasi pemilu dan jumlah keterwakilan dalam legislatif, namun yang perlu dilihat adalah adanya keseriusan dari Pemerintah dalam memperjuangkan hak-hak kaum perempuan ini melalui penerapan aturan.

Jika kita mengacu pada kata setara memang itu ada dalam proporsi seimbang atau 50: 50. Namun perlu dingat bahwa pencapaian keseteraan melawati rangkaian proses yang dimulai secara bertahap dengan spirit tidak mengguncang stabilitas yang telah terbangun akibat hukum atau aturan yang telah ada sebelumnya atau dianut oleh masyarakat. Memang diketahui dalam Undang-Undang No. 2 Tahun 2008 tentang Partai Politik yang terakhir telah diubah dengan Undang-Undang 2 Tahun 2011 tentang Partai Politik dan Undang-Undang No. 10 Tahun 2008 tentang Pemilihan Umum Anggota DPR, DPD, dan DPRD yang terakhir diganti dengan Undang-Undang No. 8 Tahun 2012 tentang Pemilihan Umum Anggota DPR, DPD, dan DPRD, kedua Undang-undang ini merumuskan aturan tentang bentuk diskriminasi positif (affirmative action) berupa kuota 30\% bagi perempuan di ranah politik Indonesia. Atau sering distilahkan keterwakilan perempuan dalam pemilihan. Namun jangan dipandang $30 \%$ keterwakilan perempuan ini sebagai pendiskriminasian kaum perempuan berpolitik, namun justru adanya angka $30 \%$ ini dalam hukum positif menjadi jaminan keberlangsungan kaum perempuan untuk turut dalam berpolitik, karena jika tidak ada aturan ini bisa jadi kaum perempuan akan tergerus dalam proses pencalonan dan pemilihan, mengingat masih tingginya anggapan masyarakat akan laki-laki sebagai pemimpin. Ani Widyani Soetjipto, mendefinisikan secara umum affirmative action sebagai tindakan pro-aktif untuk menghilangkan perlakuan diskriminasi terhadap satu 
kelompok sosial yang masih terbelakang (Ani Widyani Soetjipto, 2005). Koalisi Perempuan Indonesia, mengatakan bahwa affirmative action atau diskriminasi positif merupakan kebijakan, peraturan atau program khusus yang bertujuan untuk mempercepat persamaan posisi dan kondisi yang adil bagi kelompok-kelompok yang termarjinalisasi dan lemah secara sosial dan politik, seperti kelompok miskin, penyandang cacat, buruh, petani, nelayan dan lain-lain, termasuk di dalamnya kelompok perempuan (Koalisi Perempuan Indonesia, 2002). Sedangkan Shidarta (2008), mengemukakan bahwa tindakan affirmatif (affirmative action) diartikan sebagai upaya meningkatkan hak atau kesempatan bagi orang yang semula tidak/kurang beruntung (disadvantaged) agar dapat mengenyam kemajuan dalam waktu tertentu.

Dengan melihat beberapa pendapat di atas dapat dikatakan bahwa untuk mengejar suatu ketertinggalan perlu dilakukan langkah-langkah kongkrit yang memang tidak senantiasa menyebabkan posisi ketertinggalan tersebut menjadi seimbang atau sama, namun paling tidak ada suatu langkah lompatan yang menyebabkan kaum perempuan jauh dari kesan tertinggal dan mulai ada penyetaraan, seperti yang terlihat dalam Undang-undang pemilu dan partai politik yang membuka peluang bagi kaum perempuan untuk sejajar dengan kaum pria melalui kuota $30 \%$ ini. Perjuangan perempuan dalam meningkatkan representasi perempuan di legislatif melalui affirmative action dapat dilakukan dengan melibatkan kaum perempuan lebih banyak aktif di partai politik. Memberdayakan perempuan dalam partai politik adalah merupakan langkah paling awal untuk mendorong agar kesetaraan dan keadilan bisa dicapai antara laki-laki dan perempuan di dunia publik dalam waktu tidak terlalu lama. Langkah ini diperlukan agar jumlah perempuan di lembaga legislatif bisa seimbang jumlahnya dengan laki-laki. Dengan adanya angka kuota ini diharapkan membuat kaum perempuan terpacu untuk meningkatkan kemauan dan kemampuan, tidak justru sebaliknya tidak mau berjuang, sehingga membuat adanya aturan kuota ini menjadi mubazir.

\section{B. Pencapaian Perempuan Bali dalam Pemilihan Umum Legislatif di Bali}

Perempuan di Bali dahulunya, sangat terkenal dengan adat ketimuran yang menjunjung kesopanan serta adat istiadat setempat. Dengan menerapkan sistem perkawinan Patrilinial yang dianut oleh masyarakat Hindu di Bali, menyebabkan kaum perempuan senantiasa mendampingi dan mengikuti sang suami. Hal ini sangat berkaitan dengan kepemimpinan di rumah tangga atau keluarga yang sebagian besar di pegang oleh kaum perempuan. Namun dalam beberapa aturan hukum adat di Bali, masih ada kemungkinan perempuan bertindak selaku purusha (dalam kasus nyentana atau meras lanang), namun hal ini tidak serta merta mengakibatkan perempuan bertindak selaku kepala atau pemimpin keluarga. Oleh karenanya 
dari masa dahulu kepemimpinan di bali tidak lepas dari kaum pria.

Walaupun keberadaan kaum perempuan di Bali tidak dapat lepas dari bayang-bayang kepemimpinan kaum pria, kedudukan mereka baik di masyarakat maupun agama tetap dihormati, namun demikian kaum perempuan tetap dapat kesempatan atau kehormatan dalam memangku suatu jabatan di luar keluarga berdasarkan kemampuan atau kecakapan, sehingga merekapun dengan kemampuan yang dimiliki tersebut dapat dipilih sebagai pemimpin atau wakil masyarakat. Seperti yang tertuang dalam Kitab Artha Sastra, disebutkan "ia hendaknya mengangkat pemimpin yang memiliki kemampuan dari lahir, kecerdasan, integritas, keberanian, loyalitas dan kualitas, bukan karena hal yang lain" (Astana Made, 2005). Dari hal ini dapat dilihat bahwa seorang pemimpin tidak diangkat berdasarkan jenis kelaminnya, namun berdasarkan kemampuan yang dimiliki, sehingga benar-benar bisa mensejahterakan masyarakatnya.

Berbicara

kepemimpinan perempuan di Bali tentu kita dapat bandingkan dengan pencapaian perempuan Bali saat ini yang dilihat dari keterwakilan perempuan di parlemen. Keterwakilan perempuan Bali di parlemen sejauh ini masih tergolong sangat minim. Di pentas politik lokal Bali misalnya dapat diamati dari jumlah perempuan yang duduk sebagai legislator, masih jauh dari kata setara dengan kaum pria. Pada Pemilu 2004 contohnya, keterwakilan perempuan di DPRD Provinsi Bali hanya 5,4 persen (tiga orang dari lima puluh lima anggota DPRD terpilih). Selanjutnya pada Pemilu 2009 persentase keterwakilan perempuan naik menjadi 7,3 persen (empat orang dari lima puluh lima anggota DPRD terpilih). Sedangkan di Pemilu 2014 lalu, keterwakilan perempuan baru sebesar 9 persen (lima orang dari lima puluh lima anggota DPRD terpilih) dan di tahun 2019 lalu, keterwakilan perempuan di DPRD Provinsi Bali melalui hasil pemilu yang sudah dirilis mencapai lonjakan yang cukup baik yakni sebesar 16,4 $\%$ (Sembilan orang dari lima puluh lima Calon Anggota DPRD terpilih).

Adapun nama wakil perempuan yang lolos kursi DPRD Provinsi Bali yakni: dari PDIP yakni caleg petahana Ni Kadek Darmini (34.712 suara), dan IGA Diah Werdhi Srikandi (28.051 suara). Serta empat caleg New Comer atau pendatang baru Ni Wayan Sari Galung (26.210 suara), I Gusti Ayu Aries Sujati (32.408 suara), Ni Luh Kadek Dwi Yustiawati (24.079 suara), dan $\mathrm{Ni}$ Luh Yuniati (37.315 suara). Sementara caleg di luar PDIP yakni caleg incumbent dari Partai Golkar Dapil Karangasem Ni Putu Yuli Artini (20.142 suara), caleg incumbent dari Partai Demokrat Utami Dwi Suryadi (5.736 suara). serta caleg partai pendatang baru dari PSI, Grace Anastasia Surya Widjaja (4.315 suara). (Radar Bali, 30 Juli 2019 ).

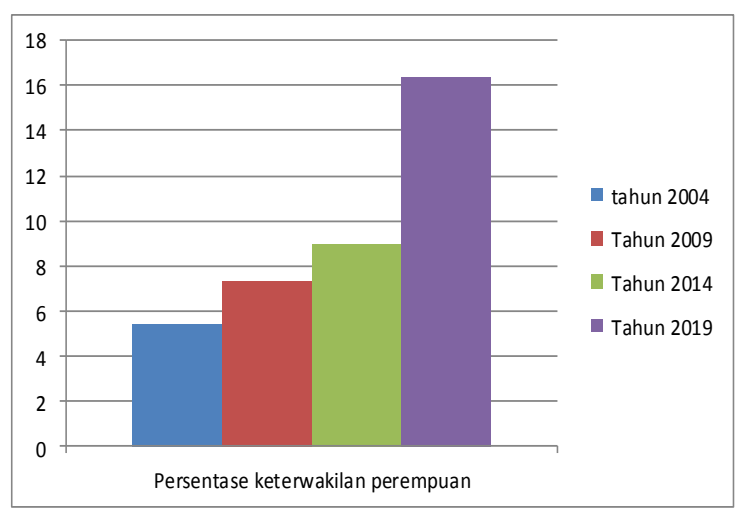

Gambar 1. Pesentase Keterwakilan

Perempuan di DPRD Provinsi Bali

Dengan melihat perkembangan kenaikkan persentasi keterwakilan perempuan Bali di legislatif, menandakan perjuangan perempuan 
Bali untuk menggapai kesetaraan tersebut sangat tinggi dan menunjukkan trend yang baik. Hal ini tidak terlepas dari sudah mulai terbukanya pemahaman masyarakat tentang persamaan kesempatan dan kepercayaan kepada kaum perempuan. Tidak hanya di legislatif di eksekutifpun perempuan Bali sudah mulai berbicara banyak seperti munculnya figur - figur pemimpin perempuan di daerah kabupaten di pucuk pimpinan tertinggi, seperti: Mas Sumantri (Bupati Karangasem saat ini), dan Eka Wiryastuti (Bupati Tabanan saat ini) jika dipersentasikan keterwakilan perempuan sebagai pimpinan eksekutif ini sebesar 22,22\% dari jumlah pimpinan kabupaten/kota yang ada di Bali.

\section{PENUTUP}

Dari urian di atas dapat disimpulkan bahwa Undang-Undang tentang Pemilu memberikan suatu jaminan bagi kaum perempuan dalam keterlibatannya dibidang politik dan demokrasi, walaupun penjaminan keterlibatan tersebut belum mampu mensejajarkan keterwakilan wanita, namun paling tidak adanya ketentuan $30 \%$ kuota perempuan tersebut semakin menipiskan jurang ketertinggalan kaum perempuan dalam berpolitik. Khusus mengenai penerapan aturan tersebut bagi kaum perempuan di Bali sudah mulai menunjukkan peningkatan keterwakilan kaum perempuan di parlemen. Hal ini dapat dilihat dari hasil pemilihan Umum DPRD tingkat Provinsi dari tahun 2004 hingga pemilihan 2019 yang menunjukkan akan peningkatan keterwakilan perempuan yang cukup menggembirakan, dari $4,5 \%$ di tahun $2004,7,3 \%$ di tahun $2009,9 \%$ di tahun 2014, hingga lonjakkan $16,4 \%$ di tahun
2019. Diharapkan dengan adanya ketentuan tersebut ada semangat dari kaum perempuan untuk terpacu menggunakan hak-hak mereka sehingga kemauan dan kemampuan yang mereka miliki dalam berpolitik dan berdemokrasi dapat digunakan dalam rangka mempertahankan eksistensi kaum perempuan ini.

\section{DAFTAR PUSTAKA}

Ani Widyani Soetjipto, Politik Perempuan Bukan Gerhana, Jakarta: Penerbit Buku Kompas, 2005.

Astana, Made, Cs, Artha Sastra, Surabaya: Paramita, 2005.

Koalisi Perempuan Indonesia, Tindakan Khusus Sementara : Menjamin Keterwakilan Perempuan, Pokja Advokasi Kebijakan Publik Sekretariat Nasional Koalisi Perempuan Indonesia, Oktober 2002.

Mardanas Safwan dan Sutrisno Kutoyo, R.A. Kartini: riwayat hidup dan perjuangannya, Jakarta: Mutiara Sumber Widya, 2001.

Mansour Fakih, Analisis Gender \& Transformasi Sosial, Yogyakarta: Pustaka Pelajar, 2004.

Moempoeni Martojo, Moempoeni Martojo,Prinsip Persamaan di Hadapan hukum bagi Wanita dan Pelaksanaannya di Indonesia, Disertasi, Semarang: Universitas Dipenogoro (UNDIP), 1999. 
Shidarta, Konsep Diskriminasi Dalam Perspektif Filsafat Hukum, (Dalam "Butir-butir Pemikiran Dalam Hukum" memperingati 70 Tahun Prof. Dr. B. Arief Sidharta,SH), Bandung: Refika Aditama, 2008.

https://id.wikipedia.org/wiki/Pemimpin w anita di Indonesia akses: 1 Juli 2019 